\title{
HUBUNGAN KARAKTERISTIK SOSIODEMOGRAFI DENGAN STATUS GIZI SISWA SEKOLAH DASAR
}

\author{
Tiffany Konstantin ${ }^{1)}$, Indah Setyawati Tantular ${ }^{2)}$, Alpha Fardah Athiyyah ${ }^{3)}$, Lynda Rossyanti ${ }^{4)}$ \\ ${ }_{1}$ Program Studi Kedokteran, Fakultas Kedokteran, Universitas Airlangga \\ email: tiffanykonstantin@yahoo.com \\ ${ }_{2}$ Departemen Parasitologi, Fakultas Kedokteran, Universitas Airlangga \\ ${ }_{3}$ Departemen Ilmu Kesehatan Anak, Rumah Sakit Umum Dr. Soetomo \\ ${ }_{4}$ Departemen Parasitologi, Fakultas Kedokteran, Universitas Airlangga
}

\begin{abstract}
Abstrak
Status gizi adalah kondisi fisiologis tubuh terkait konsumsi makanan dan penggunaan zat gizi oleh tubuh. Hingga sekarang, masalah gizi masih umum terjadi terutama di negara berkembang. Status gizi pada siswa sekolah dasar penting karena dapat mempengaruhi kognitif dan capaian pembelajaran siswa. Salah satu akar masalah gizi adalah kemiskinan yang terkait dengan sosiodemografi yang meliputi status sosial dan ekonomi. Tujuan penelitian ini adalah untuk menganalisis hubungan karakteristik sosiodemografi dan status gizi siswa sekolah dasar di Desa Wokam dan Desa Karangguli, Kabupaten Kepualaun Aru, Maluku. Penelitian ini menggunakan rancangan cross-sectional dan jenis penelitian ini adalah analitik observasional. Penilaian status gizi menggunakan grafik berat badan terhadap tinggi badan dengan kriteria Waterlow. Data mengenai sosiodemografi dikumpulkan dengan wawancara. Hubungan antara karakteristik sosiodemografi dan status gizi dinilai dengan uji statistik chi-square. Dari 106 sampel, 73 siswa (68,9\%) memiliki status gizi normal dan 33 siswa (31,1\%) memiliki status gizi kurang. Uji statistik tidak menunjukkan hubungan yang signifikan antara karakteristik sosiodemografi dan status gizi di Desa Wokam dan Karangguli, Kabupaten Kepulauan Aru.
\end{abstract}

Kata kunci: hubungan, siswa sekolah dasar, sosiodemografi, status gizi

\begin{abstract}
Nutritional status is a physiological condition of the body related to food consumption and requirements of the body. Until now, malnutrition is a common problem in developing countries. Nutritional status in school age children is important because it can affect cognitive ability and student achievement. One of the root problems of malnutrition is poverty which is related to sociodemographic including social and economic status. The purpose of this study is to analyze the correlation between sociodemographic characteristics and nutritional status in elementary school children in Wokam and Karangguli Village, Aru Islands Regency, Maluku. This study used cross-sectional study design and the type of this study is analytical observational. Nutritional status was assessed using weight to stature growth chart with Waterlow criteria. Data about sociodemographic were collected by interview. Correlation between sociodemographic characteristics and nutritional status were analyzed using chi-square test. From 106 samples, 73 students $(68,9 \%)$ have normal nutritional status and 33 students $(31,1 \%)$ were wasted. No significant correlation was found between sociodemographic characteristics and nutritional status in Wokam and Karangguli Village, Aru Islands Regency.
\end{abstract}

Keywords: correlation, elementary school students, nutritional status, sociodemographic

\section{PENDAHULUAN}

Status gizi adalah kondisi fisiologis tubuh terkait konsumsi makanan dan penggunaan zat gizi oleh tubuh yang berhubungan dengan kemampuan tubuh untuk mencerna dan menyerap nutrisi yang dikonsumsi. Masalah gizi masih umum terjadi di negara berkembang termasuk Indonesia. Status gizi yang tidak sesuai standar dikenal dengan istilah malnutrisi. Status gizi siswa sekolah dasar merupakan hal yang penting karena kelompok usia sekolah dasar adalah kelompok usia di mana siswa banyak mendapatkan ilmu dasar dan informasi 
baru. Status gizi yang buruk dapat mempengaruhi kognitif dan capaian pembelajaran dari siswa sekolah dasar (Best et al., 2010).

Status gizi yang baik adalah dasar untuk tumbuh kembang manusia di setiap tahap kehidupan. Malnutrisi dapat mengakibatkan komplikasi kesehatan seperti penyakit infeksi. Salah satu akar dari masalah gizi adalah kemiskinan. Angka kemiskinan di Indonesia pada tahun 2018 adalah 25,95 juta orang (9,82\%). Akan tetapi, angka kemiskinan cenderung lebih tinggi di daerah pedesaan. Berdasarkan data dari Badan Pusat Statistik, angka kemiskinan di lokasi penelitian yaitu Kabupaten Kepulauan Aru adalah 25.680 penduduk miskin $(27,12 \%)$ (Badan Pusat Statistik, 2019). Pada Riskesdas 2018, prevalensi status gizi kurus dan sangat kurus anak usia 5-12 tahun di Maluku memiliki persentase di atas ratarata Indonesia (Kementerian Kesehatan Republik Indonesia, 2019).

Pedoman Ikatan Dokter Anak Indonesia (IDAI) merekomendasikan penentuan status gizi untuk anak lebih dari 5 tahun menggunakan grafik Centers for Disease Control and Prevention (CDC) 2000 berdasarkan berat badan (BB) menurut tinggi badan (TB). Kriteria status gizi menggunakan $\mathrm{BB} / \mathrm{TB}$ (\% median) terbagi menjadi gizi buruk, gizi kurang, normal, dan potensi gizi lebih. Untuk anak yang memiliki potensi gizi lebih, dilakukan penilaian overweight atau obesitas menggunakan grafik Indeks Massa Tubuh (IMT) CDC 2000 (Ikatan Dokter Anak Indonesia, 2011).

Banyak faktor yang mempengaruhi status gizi siswa sekolah dasar antara lain sosial ekonomi, kesehatan, dan lingkungan. Pada sebuah penelitian, krisis ekonomi dapat mengakibatkan naiknya anak dengan gizi kurang. Pekerjaan juga berhubungan dengan tingkat penghasilan dan ekonomi rumah tangga yang mempengaruhi status gizi. Rendahnya gizi kurang dapat dikaitkan dengan peningkatan kondisi lingkungan, sosial, ekonomi, dan asupan makanan (Pongou et al., 2006).

Sosiodemografi terkait dengan status sosial dan ekonomi. Status sosioekonomi, kepadatan rumah, dan pendidikan orang tua yang rendah masih mengakibatkan tingginya angka malnutrisi karena mempengaruhi kebiasaan makan (Galgamuwa et al., 2017).

Oleh karena pentingnya peran status gizi pada siswa sekolah dasar, penelitian mengenai hubungan antara karakteristik sosiodemografi dan status gizi diperlukan untuk membantu penanggulangan masalah gizi di Indonesia. Tujuan penelitian ini adalah untuk menganalisis hubungan karakteristik sosiodemografi dengan status gizi siswa sekolah dasar di SD Inpres Karangguli dan SD Negeri Wokam, Kabupaten Kepualaun Aru, Maluku.

\section{METODE PENELITIAN}

Jenis penelitian ini adalah analitik observasional dengan rancangan penelitian crosssectional. Dengan jenis penelitian analitik observasional, pengambilan data dilakukan tanpa melakukan intervensi. Rancangan penelitian crosssectional dilaksanakan pada satu titik waktu. Pengambilan data dilakukan pada bulan Agustus 2018 di Desa Karangguli dan Desa Wokam, Kabupaten Kepulauan Aru, Maluku. Instrumen yang digunakan adalah meteran dan timbangan untuk mengukur tinggi badan dan berat badan. Penentuan status gizi dengan cara antropometri, dan pertanyaan mengenai karakteristik sosiodemografi dengan wawancara. Data mengenai karakteristik sosiodemografi yang ditanyakan adalah jenis kelamin, usia, pendidikan orang tua, pekerjaan orang tua, dan jumlah penghuni dalam rumah.

Pengambilan data dilakukan dengan teknik total sampling sesuai kriteria inklusi dan eksklusi. Kriteria inklusi adalah siswa yang bersedia menjadi subjek penelitian dan kriteria eksklusi adalah siswa yang tidak menjawab wawancara secara lengkap. Jumlah siswa yang memenuhi kriteria inklusi dan eksklusi adalah 106 siswa. Data yang didapat kemudian diolah dengan program SPSS dan disajikan dalam bentuk tabel. Analisis bivariat menggunakan uji chi-square dan nilai $p$ $<0,005$ berarti terdapat hubungan signifikan.

Penilaian status gizi pada penelitian ini menggunakan grafik BB/TB CDC 2000 untuk anak usia >5-18 tahun. Penentuan status gizi menggunakan persentase berat badan ideal sesuai kriteria Waterlow. Kriteria Waterlow menggunakan \% median $\mathrm{BB} / \mathrm{TB}$ untuk menentukan status gizi. Penilaian gizi berdasarkan berat badan menurut tinggi badan digunakan untuk menilai status nutrisi sekarang. Dalam populasi, berat badan dan tinggi badan bersifat independen terhadap umur terutama pada usia 1-10 tahun.

Penelitian ini telah dinyatakan laik etik oleh Komite Etik Penelitian Kesehatan Fakultas Kedokteran Universitas Airlangga Surabaya. Subjek penelitian telah diberi information for consent dan informed consent pada saat pengambilan data.

\section{HASIL DAN PEMBAHASAN}

Berat badan dan tinggi badan tiap siswa diukur di sekolah masing-masing untuk 
menentukan status gizi. Berat badan siswa dibandingkan dengan berat badan ideal (persentil 50) sesuai dengan tinggi badan pada kurva CDC 2000 berat badan terhadap tinggi badan. Hasil tersebut kemudian dikalikan $100 \%$ untuk melihat persentase BB/TB (\% median). Status gizi siswa tersebut kemudian diklasifikasikan berdasarkan kriteria Waterlow menjadi normal, gizi kurang, dan gizi buruk. Status gizi subjek penelitian di kedua desa terdistribusi menjadi dua: gizi kurang dan normal. Tidak ada siswa dengan status gizi buruk dari subjek penelitian. Distribusi status gizi pada penelitian ini disajikan pada tabel 1 .

Tabel 1. Distribusi Status Gizi

\begin{tabular}{ccc}
\hline Status Gizi & N & $\%$ \\
\hline Normal & 73 & 68,9 \\
Gizi Kurang & 33 & 31,1 \\
\hline
\end{tabular}

Distribusi status gizi paling banyak adalah status gizi normal $(68,9 \%)$. Penilaian status gizi menggunakan pedoman IDAI yaitu sesuai kategori
Waterlow berdasarkan \% median grafik $\mathrm{BB} / \mathrm{TB}$ CDC 2000. Status gizi tergolong normal jika \% median >90, gizi kurang jika $\%$ median 70-90, dan gizi buruk jika \% median $<70$.

Berdasarkan data pada penelitian ini, persentase siswa dengan status gizi kurang berada di atas dari rata-rata prevalensi status gizi kurus di provinsi Maluku yaitu 11,5\% (Kementerian Kesehatan Republik Indonesia, 2019). Status gizi yang kurang dapat menyebabkan dampak buruk pada pertumbuhan dan perkembangan pada anak. Salah satu dampak dari gizi buruk kronis pada anak adalah munculnya kehamilan dengan Kurang Energi Kronis (KEK) pada saat dewasa. Kehamilan dengan KEK akan menyebabkan lahirnya anak dengan status gizi kurang dan siklus ini dapat berulang apabila belum ditanggulangi secara komprehensif (Food and Agriculture Organization, 2007).

Hasil analisis bivariat karakteristik subjek penelitian dan distribusi status gizi disajikan pada tabel 2. Analisis bivariat diuji dengan uji chisquare.

Tabel 2. Analisis Bivariat Karakteristik Subjek Penelitian dan Distribusi Status Gizi

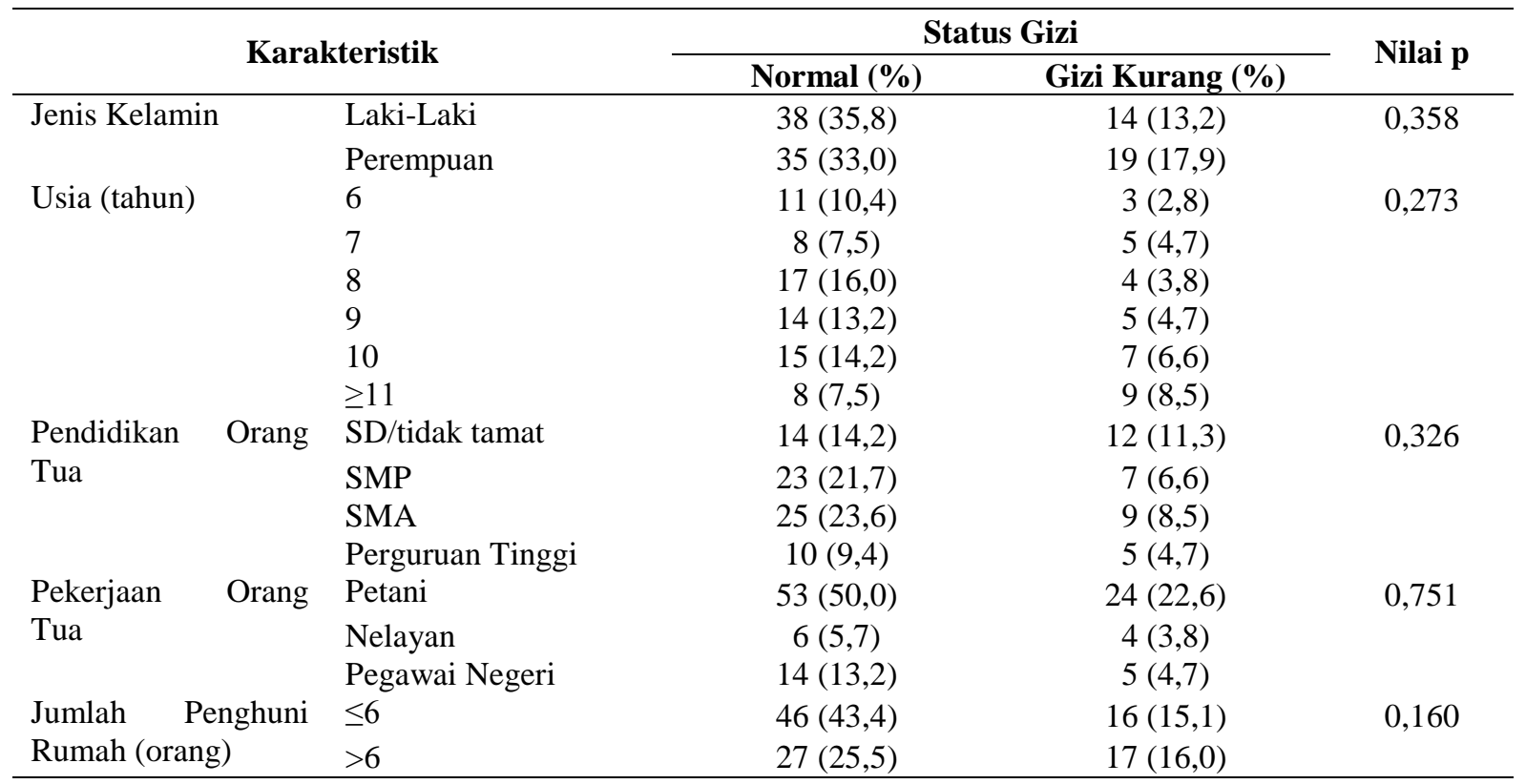

Pembagian karakteristik pada penelitian ini dibagi menjadi pembagian karakteristik berdasarkan jenis kelamin, usia, pendidikan orang tua, pekerjaan orang tua, dan jumlah penghuni dalam rumah.

Berdasarkan penelitian ini, distribusi jenis kelamin pada status gizi normal memiliki perbandingan yang cukup sebanding antara jenis kelamin laki-laki : perempuan. Sedangkan, pada siswa dengan gizi kurang didominasi dengan anak dari jenis kelamin perempuan walaupun uji statistik tidak menunjukkan hubungan yang signifikan (nilai $\mathrm{p}=0,358$ ). Hasil ini menunjukkan bahwa perhatian gizi pada siswa perempuan termasuk kurang dibandingkan dengan perhatian gizi pada siswa laki-laki. Hasil ini berbeda dengan hasil sebuah penelitian di Sumatera di mana status gizi siswa laki-laki lebih banyak yang mengalami gizi buruk maupun gizi kurang dikarenakan banyaknya aktivitas fisik laki-laki (Seprianty et al., 
2015). Hal ini dapat berhubungan dengan tradisi serta prinsip budaya di lokasi penelitian di mana anak laki-laki lebih diutamakan dari yang perempuan untuk memilih makanan lebih dahulu dan aktivitas fisik anak laki-laki dan perempuan tidak berbeda. Hasil ini sesuai dengan sebuah penelitian di India di mana gizi kurang pada perempuan lebih banyak akibat adanya budaya mengutamakan anak laki-laki (Srivastava et al., 2012).

Pembagian distribusi usia pada penelitian ini dimulai dari usia 6 tahun sampai diatas 11 tahun. Status gizi pada siswa berusia $6-10$ tahun didominasi oleh gizi normal. Berbeda halnya dengan siswa berusia $\geq 11$ tahun yang didominasi oleh subjek berstatus gizi kurang. Uji statistik antara usia siswa dan status gizi tidak menunjukkan hubungan yang signifikan (nilai $\mathrm{p}=$ 0,273). Meskipun demikian, dapat terlihat perbedaan pada status gizi siswa dengan usia lebih rendah (usia 6,7, dan 8 tahun) dibandingkan dengan siswa berusia lebih tinggi di mana status gizi kurang lebih banyak terjadi pada seiring bertambahnya usia. Tren ini menunjukkan kecukupan gizi yang lebih rendah pada siswa berusia lebih tinggi. Hal ini dapat disebabkan oleh kurangnya pengetahuan orang tua akan pertambahan kebutuhan gizi, tingginya angka kesakitan seiring bertambah usia, naiknya kebutuhan akibat meningkatnya aktivitas harian. Salah satu cara untuk mengurangi dampak ini adalah edukasi kepada orang tua serta pemberian tambahan gizi apabila diperlukan pada anak/keluarga. Kecukupan gizi pada anak yang sedang bertumbuh dan berkembang dapat mencegah penyakit-penyakit komplikasi gizi seperti stunting. Stunting merupakan akibat dari malnutrisi kronis dan pada sebuah penelitian di Ghana, angka stunting didapatkan lebih tinggi pada anak usia 10 tahun atau lebih akibat paparan malnutrisi kronis yang lebih lama (Owusu et al., 2016).

Status gizi pada siswa dengan pendidikan orang tua SD/tidak tamat, SMP, SMA, dan perguruan tinggi didominasi dengan status gizi normal. Secara statistik, distribusi pendidikan orang tua dan status gizi subjek penelitian tidak menunjukkan hasil yang signifikan (nilai $\mathrm{p}=$ 0,362). Persentase status gizi kurang paling tinggi didapatkan pada siswa dengan orang tua dengan pendidikan terakhir SD atau lebih rendah. Untuk siswa dengan orang tua yang pendidikan terakhirnya SMP atau lebih tinggi menunjukkan siswa yang status gizi normal lebih dari dua kali dibandingkan dengan status gizi kurang. Pendidikan orang tua berkaitan dengan pengetahuan orang tua mengenai asupan nutrisi yang sesuai dengan usia. Selain itu, pendidikan orang tua juga berkaitan dengan pekerjaan orang tua di mana pendidikan yang lebih tinggi dapat mendapat penghasilan yang lebih banyak (Sebataraja et al., 2014)

Siswa dengan orang tua yang memiliki pekerjaan petani, nelayan, dan pegawai negeri didominasi dengan status gizi normal. Pekerjaan orang tua yang paling banyak di lokasi penelitian adalah petani. Pada siswa dengan status gizi kurang, pekerjaan orang tua yang paling banyak adalah petani. Uji statistik antara pekerjaan orang tua dan status gizi pada penelitian ini tidak menunjukkan hasil signifikan (nilai $p=0,751$ ). Hal ini terkait dengan banyaknya faktor yang mempengaruhi status gizi seperti asupan makanan. Pada penelitian Astuti di Yogyakarta, tidak adanya hubungan yang signifikan antara pendapatan dan status gizi karena pendapatan keluarga masih mencukupi kebutuhan makanan. Pendapatan yang memadai tidak sebanding lurus dengan status gizi karena perlunya pengetahuan orang tua mengenai asupan gizi yang sesuai memadai (Astuti et al., 2012). Orang tua yang bekerja juga dapat mengakibatkan tidak adanya waktu untuk mempersiapkan bekal untuk anak sehingga anak tidak mengonsumsi makanan yang sesuai dengan standar gizi seimbang (Galgamuwa et al., 2017)

Jumlah penghuni satu rumah di lokasi penelitian terdistribusi dari 3 orang sampai 12 orang, dengan jumlah penghuni satu rumah terbanyak adalah 4 orang sebanyak 21 siswa. Jumlah rata-rata penghuni satu rumah di lokasi penelitian adalah 6,28 orang. Siswa dengan jumlah penghuni satu rumah kurang dari sama dengan maupun lebih dari enam orang didominasi dengan status gizi normal. Jumlah orang dalam rumah berkaitan dengan pertumbuhan anak yang lebih baik. Pada sebuah penelitian di Padang, terdapat hubungan yang signifikan antara jumlah anak dalam keluarga dan status gizi. Akan tetapi pada penelitian ini, uji statistik tidak menunjukkan hubungan yang signifikan antara jumlah orang dalam rumah dan status gizi. Walaupun tidak signifikan, persentase gizi kurang pada penelitian ini didapatkan lebih tinggi pada siswa yang jumlah penghuni satu rumahnya lebih dari 6 orang. Pada sebuah penelitian di Ethiopia, ukuran keluarga yang besar berhubungan positif dengan status gizi kurang karena ketidakseimbangan distribusi makanan dalam rumah (Herrador et al., 2014). Selain itu, jumlah penghuni satu rumah yang banyak dapat mengakibatkan kondisi sanitasi yang buruk sehingga angka penyakit infeksi dapat meningkat. Infeksi merupakan salah satu faktor yang meningkatkan angka gizi buruk karena kebutuhan tubuh yang 
meningkat. Hal ini mengakibatkan suatu siklus infeksi dan gizi buruk. Intervensi dapat dilakukan dengan terapi infeksi dan perbaikan asupan makanan untuk memutus siklus tersebut (Galgamuwa et al., 2017). Hasil yang tidak signifikan pada penelitian ini dapat dipengaruhi beberapa faktor yang tidak diteliti seperti luas rumah. Selain itu, konsumsi dalam keluarga lebih dipengaruhi pendapatan keluarga dibandingkan jumlah orang dalam rumah (Sebataraja et al., 2014).

\section{REFERENSI}

Astuti, F.D., \& Sulistyowati, T.F. (2012). Pendapatan Keluarga dengan Status Gizi Anak Prasekolah dan Sekolah Dasar Di Kecamatan Godean. Kesmas, 7 (1), 15-20.

Badan Pusat Statistik. (2019). Data Dan Informasi Kemiskinan Kabupaten/Kota Tahun 2018. Jakarta: Badan Pusat Statistik.

Best, C., Neufingerl, N., van Geel, L., van den Briel, T., \& Osendarp, S. (2010). The Nutritional Status of School-Aged Children: Why Should We Care. Food and Nutrition Bulletin, 31 (3), 400-417.

Food and Argiculture Organization. (2007). Nutritional Status and Food Security: Learner Notes. European Union: Food and Argiculture Organization.

Galgamuwa, L.S., Iddawela, D., Dharmaratne, S.D., \& Galgamuwa, G.L.S. (2017). Nutritional status and correlated socio-economic factors among preschool and school children in plantation communities, Sri Lanka. BMC Public Health, 17 (377).

Herrador, Z., Sordo, L., Gadisa, E., Moreno, J., Nieto, J., Benito, A., Aseffa, A., Cañavate, C., \& Custodio, E. (2014) Cross-Sectional Study of Malnutrition and Associated Factors among School Aged Children in Rural and Urban Settings of Fogera and Libo Kemkem Districts, Ethiopia. PLOS ONE, 9 (9), e105880.

\section{KESIMPULAN DAN SARAN}

Prevalensi gizi kurang di lokasi penelitian masih di atas rata-rata yaitu $31,1 \%$. Tidak didapatkan hubungan yang signifikan antara karakteristik sosiodemografi dengan status gizi pada penelitian ini. Saran untuk penelitian lanjutan adalah meneliti faktor pola asuh dan asupan makanan yang dapat mempengaruhi status gizi untuk menentukan faktor determinan tingginya status gizi kurang.

Ikatan Dokter Anak Indonesia. (2011). Asuhan Nutrisi Pediatrik. Jakarta: Ikatan Dokter Anak Indonesia.

Kementerian Kesehatan Republik Indonesia. (2019). Laporan Nasional Riskesdas 2018. Jakarta: Badan Penelitian dan Pengembangan Kesehatan

Owusu, J., Colecraft, E., Aryeetey, R., Vaccaro, J., \& Huffman, F. (2017). Nutrition Intakes and Nutritional Status of School Age Children in Ghana. Journal of Food Research, 6 (2), 11-23.

Pongou, R., Ezzati, M. \& Salomon, J.A. (2006). Household and community socioeconomic and environmental determinants of child nutritional status in Cameroon. BMC Public Health, 6 (98).

Sebataraja, L.R., Oenzil, F., \& Asterina. (2014). Hubungan Status Gizi dengan Status Sosial Ekonomi Keluarga Murid Sekolah Dasar di Daerah Pusat dan Pinggiran Kota Padang. Jurnal Kesehatan Andalas, 3 (2), 182-187.

Seprianty, V., Tjekyan, R.M.S., \& Thaha, M.A. (2015). Status Gizi Anak Kelas III Sekolah Dasar Negeri 1 Sungaililin. Jurnal Kedokteran dan Kesehatan, 2 (1), 129-134.

Srivastava, A., Mahmood, S. E., Srivastava, P. M., Shrotriya, V. P., \& Kumar, B. (2012). Nutritional status of school-age children - A scenario of urban slums in India. Arch Public Health, 70 (8). 